\title{
Purification and Characterization of Six Fibrinolytic Serine-Proteases from Earthworm Lumbricus rubellus
}

\author{
Il Hwan Cho, Eui Sung Choi ${ }^{\dagger}$ Hun Gil Lim and Hyung Hoan Lee* \\ Department of Biological Sciences, Konkuk University, Seoul 143-701, Korea \\ 'Lab of Microbial Functions, Korea Research Institute of BioSciences and Biotechnology, Daejon 305-333, Korea \\ College of Medicine, Hanyang University, Seoul 133-791, Korea
}

Received 20 May 2003, Accepted 8 July 2003

\begin{abstract}
The six lumbrokinase fractions (F1 to F6) with fibrinolytic activities were purified from earthworm Lumbricus rubellus lysates using the procedures of autolysis, ammonium sulfate fractionation, and column chromatography. The proteolytic activities on the casein substrate of the six iso-enzymes ranged from 11.3 to 167.5 unit/mg with the rank activity orders of F2 > F1 > F5 > F6 $>$ F3 $>$ F4. The fibrinolytic activities of the six fractions on the fibrin plates ranged from 20.8 to $207.2 \mathrm{unit} / \mathrm{mg}$ with rank orders of F6 $>$ F2 $>$ F5 $>$ F3 $>$ F1 $>$ F4. The molecular weights of each iso-enzyme, as estimated by SDS-PAGE, were 24.6 (F1), 26.8 (F2), 28.2 (F3), 25.4 (F4), 33.1 (F5), and 33.0 kDa (F6), respectively. The plasminogen was activated into plasmin by the enzymes. The optimal temperature of the six iso-enzymes was $50^{\circ} \mathrm{C}$, and the optimal pH ranged from $\mathbf{p H}$ 4-12. The four iso-enzymes (F1-F4) were completely inhibited by PMSF. The two enzymes (F5 and F6) were completely inhibited by aprotinin, TLCK, TPCK, SBTI, LBTI, and leupeptin. The $\mathrm{N}$-terminal amino acid (aa) sequences of the first 20 to 22 residues of each fraction had high homology. All six isoenzymes had identical aa residues 2-3 and 13-15. The $\mathrm{N}$ terminal 21-22 aa sequences of the F2, F3, and F4 isoenzymes were almost the same. The N-terminal aa sequences of F5 and F6 were identical.
\end{abstract}

Keywords: Fibrin, Lumbricus rubellus, Lumbrokinase

*To whom correspondence should be addressed.

Tel: 822-450-3426; Fax: 822-452-97165

E-mail: hhlee@konkuk.ac.kr

\section{Introduction}

Fibrinolytic enzymes in the earthworm, Lumbricus rubellus, were extracted and named lumbrokinase (LK) by Mihara et al. (1991), a collective name for six fibrinolytic iso-enzyme proteins having molecular weights of 25 to $32 \mathrm{kDa}$. Several investigators purified and further characterized the fibrinolytic enzymes in L. rubellus (Park et al., 1989; Mihara et al., 1993; Nakajima et al., 1993; Jeon et al., 1995) and found the hydrolysis of the plasmogen-rich fibrin and plasmogen-free fibrin. The fibrinolytic enzymes dissolve blood fibrin clots, which are important for clinical application as chemotherapeutic agents (Mihara et al., 1989; Ryu et al., 1994, 1995; Park et al., 1999).

The differences and characteristics among the iso-enzymes should be studied further. We, therefore, undertook to purify and characterize the protease with fibrinolytic activity for use in clinical applications. The aims of this study were as follows: (1) Purify and characterize the LK enzymes from the Korean earthworm L. rubellus, (2) Determine the N-terminal amino acid sequence of the LK enzymes and determine their similarity to those of other trypsin-like serine proteases.

\section{Materials and Methods}

Animals The earthworms (Lumbricus rubellus) that were obtained from the Giheung Farmer School, Korea, were the lumbrokinase sources. A specific pathogen free, eight-week old Sprague-Dawley male mouse strain (300-350 g) was maintained at $23.1^{\circ} \mathrm{C}, 55.5 \%$ of humidity, $10-18$ times of aeration per hour, $12 \mathrm{~h}$ of light and dark with 300-500 luxes, and used for hydrolysis of a blood clot.

Purification of lumbrokinase from $L$. rubellus

Step 1. Ammonium sulfate precipitation and filtration. Ten $\mathrm{kg}$ of washed earthworms were homogenized in $\mathrm{H}_{2} \mathrm{O}$ using a homo-mixer (Janke and Kunkel GmbH CoKG, Staufen, Germany) and stored 
for $4 \mathrm{~h}$ at $45^{\circ} \mathrm{C}$ to be self-autolyzed. Next, $0.025 \%$ sodium azide was added to the homogenate solutions, which were stored for $15 \mathrm{~d}$ at room temperature for self-autolysis. After autolysis, the homogenates were centrifuged at $4,500 \times g$ for $30 \mathrm{~min}$ at $4^{\circ} \mathrm{C}$. The supernatants were collected, filtered using a celite, refiltered with a membrane filter of $0.45 \mu \mathrm{m}$ (Sartorius, Goettingen, Germany), and lyophilized (Christ, beta 1-15, Osterode, Germany). The lyophilized-crude extract powders were suspended in 51 of a 20 $\mathrm{mM}$ phosphate buffer ( $\mathrm{pH}$ 7.4). The proteins were then salted out with 30 60\% ammonium sulfate. The precipitates were suspended in 11 of a $20 \mathrm{mM}$ phosphate buffer ( $\mathrm{pH} 7.4$ ) and filtered using a membrane filter $(0.45 \mu \mathrm{m})$. The filtrates were concentrated with an ultrafilteration system (Millipore, Bedford, USA), desalted, concentrated, and lyophilized. This lyophilized powder was stocked as lumbrokinase (LK) filtrates.

Step 2. Ion exchange chromatography. The four steps of chromatography were performed according to the procedures described by Scope (1987) with modifications. The LK-filtrate powders were resolved in $500 \mathrm{ml}$ of a $20 \mathrm{mM}$ phosphate buffer $(\mathrm{pH}$ 7.4 ), filtered with membrane filters $(0.45 \mu \mathrm{m})$, and loaded on a DEAE (diethylaminoethyl)-toyopearl 650 resin (Tosoh, Yokyo, Japan) column $(4.5 \times 35 \mathrm{~cm})$ (Amicon, Danvers, USA) that was equilibrated with a $20 \mathrm{mM}$ phosphate buffer $(\mathrm{pH}$ 7.4). After loading, the adsorbed proteins were eluted with a linear gradient of $0-0.5 \mathrm{M} \mathrm{NaCl}$ in the same buffer at a flow-rate of $2 \mathrm{ml}$ per min. The three enzyme peaks were separately harvested and applied to the next step.

Step 3. Hydrophobic interaction chromatography. The peaks I or II samples of the DEAE fractions were loaded onto a phenyltoyopearl resin column $(2.0 \times 15 \mathrm{~cm})$ that was equilibrated with an ammonium sulfate buffer ( $1 \mathrm{M}$ ammonium sulfate in $20 \mathrm{mM}$ phosphate buffer, $\mathrm{pH}$ 7.4) and washed with the same buffer. The adsorbed proteins were eluted with a linear gradient of $0-1 \mathrm{M}$ ammonium sulfate at a flow rate of $1.0 \mathrm{ml}$ per min. The active peak II fractions were collected separately.

Step 4. Affinity chromatography. The peak III samples of the DEAE fractions were loaded onto a benzamidine sepharose 6B (Pharmacia, Uppsala, Sweden) column $(2.0 \times 15 \mathrm{~cm})$ that was equilibrated with a $20 \mathrm{mM}$ phosphate buffer. The adsorbed enzymes were eluted with a linear gradient of 0-0.5 M arginine in the same buffer at a flow rate of $0.8 \mathrm{ml}$ per min. A $10 \mathrm{ml}$ sample of the fraction was collected.

Step 5. Gel filtration chromatography. To remove the contaminates, all of the fractionating was done using a Sephacryl S200 (Sigma Co., St. Louis, USA) column $(2.0 \times 75 \mathrm{~cm})$. After loading, the adsorbed enzymes were eluted at a flow rate of $0.3 \mathrm{ml}$ per min with a $20 \mathrm{mM}$ phosphate buffer (pH 7.4). Ten $\mathrm{ml}$ of each fraction was collected.

Enzyme assay on casein and fibrin plates The proteolytic activities were determined using both the casein hydrolysis (Robbins and Summaria, 1972) and fibrin plate methods (Astrup and Mullertz, 1952; Park et al., 1999b; Lee et al., 2001) with slight modifications. The casein method was prepared and assayed as follows: $2 \mathrm{ml}$ of $4 \% \alpha$-casein (Sigma) as a substrate were mixed in $1.6 \mathrm{ml}$ of the $67 \mathrm{mM}$ sodium phosphate buffer ( $\mathrm{pH} 7.4)$ and $0.4 \mathrm{ml}$ of the lumbrokinase fraction $(1 \mathrm{mg} / \mathrm{ml})$, and stored for $30 \mathrm{~min}$ at $37^{\circ} \mathrm{C}$. The reaction was stopped using $6 \mathrm{ml}$ of $15 \%$ trichloroacetic acid (TCA) for $30 \mathrm{~min}$. The reactants were filtered with Whatman No. 1 filter paper (Whatman International Ltd, Maidstone, England). The proteolytic activity of the filtrated enzyme was measured at $280 \mathrm{~nm}$ using a spectrophotometer (Hewlett-Packard, Munich, Germany). The enzyme activity was determined as one unit when $450 \mu \mathrm{g}$ of the TCA-soluble tyrosine per hour was dissolved.

The fibrin plate was prepared and assayed as follows: 5\% fibrinogen solution (Sigma) was prepared in a fibrin plate (FP) buffer $\left(50 \mathrm{mM}\right.$ sodium barbital, $93 \mathrm{mM} \mathrm{NaCl}, 1.66 \mathrm{mM} \mathrm{CaCl}_{2}$, $0.96 \mathrm{mM} \mathrm{MgCl}_{2}, \mathrm{pH} 7.8$, ionic strength 0.15 ). Next, $10 \mathrm{ml}$ of the mixture was distributed into each sterile petri-dish $(8 \mathrm{~cm})$ (Nunc, Roskilde, Denmark), and $50 \mu \mathrm{l}$ of $20 \mathrm{NIH}$ units $/ \mathrm{ml}$ of the thrombin solution (Sigma) was slowly mixed and solidified for $1 \mathrm{~h}$ at room temperature. Then, 0.2-2.0 units $/ \mathrm{ml}$ sample of a human plasmin in the FP buffer was prepared for use as a fibrinolytic standard enzyme and a $10 \mu \mathrm{l}$ aliquot was plated on the fibrin plates, which were stored and incubated for $15 \mathrm{~h}$ at $37^{\circ} \mathrm{C}$. The mean diameter of the hydrolyzed clear zone was then measured. A standard curve was generated by plotting the fibrinolytic area against enzyme activity for the human plasmin. To estimate the lumbrokinase activity of each fraction, $1.0 \mathrm{mg}$ powder of each fraction per $10 \mathrm{ml}$ of the FP buffer was dissolved. Then, $10 \mu \mathrm{l}$ of the solution was plated on the fibrin plate, incubated for $15 \mathrm{~h}$ at $37^{\circ} \mathrm{C}$, and the clear zone measured. The plasmin unit was then compared to the standard curve and their differences estimated.

Measurement of molecular weights SDS-PAGE was run according to the methods of Laemmli (1970) and Choi et al., (2002) using $12 \%$ polyacrylamide gel. The samples were stained with Coomassie brilliant blue R-250. The molecular weights were calculated according to low molecular weight standards (Sigma).

Activation assay of plasminogen To detect the activation of plasminogen to plasmin by the enzymes, a plasminogen-rich fibrin plate was prepared as follows: $0.5 \%$ fibrinogen in a FP buffer and 1.0 unit of plasminogen in $1.0 \mathrm{ml}$ of a FP buffer. According to the previously mentioned method, $1.0 \mathrm{NIH}$ unit per ml of thrombin was mixed and solidified. The control was a plasminogen-free plate. Each fraction $(1.0 \mathrm{mg} / \mathrm{ml})$ was dissolved in the FB buffer, then $10 \mu \mathrm{l}$ of the mixture was dropped on the plasminogen-fibrin and control plates and incubated for $7 \mathrm{~h}$ at $37^{\circ} \mathrm{C}$. After one hour, the degree of activation for plasminogen was estimated by a comparison between the lysis area $\left(\mathrm{mm}^{2}\right)$ on the plasminogen-rich fibrin plate and the control fibrin plate.

Effect of temperature on the enzyme activity After $1.0 \mathrm{mg}$ of the enzyme powder was dissolved in $1.0 \mathrm{ml}$ of the $67 \mathrm{mM}$ phosphate buffer ( $\mathrm{pH} 7.4$ ), the enzyme activity was assayed on the casein plate according to the time period at the interval of $5^{\circ} \mathrm{C}$ from $50^{\circ} \mathrm{C}$ to $70^{\circ} \mathrm{C}$. The relative residual activity $(\%)$ was assayed in comparison with the enzyme activity at $37^{\circ} \mathrm{C}$ as a control (100\%) (Robbins and Summaria, 1976).

Effect of pH on the enzyme stability The enzyme activity was also determined in various buffers with $\mathrm{pH}$ ranges from 2 to $13 ; 0.1$ $\mathrm{M}$ glycine- $\mathrm{HCl}$ buffer for $\mathrm{pH} 2-3,0.1 \mathrm{M}$ citric acid- $\mathrm{Na}_{2} \mathrm{HPO}_{4}$ buffer for $\mathrm{pH} 3-6,0.1 \mathrm{M}$ phosphate buffer for $\mathrm{pH}$ 6-8, $0.1 \mathrm{M}$ glycine- 
$\mathrm{NaOH}$ buffer for $\mathrm{pH}$ 8-11, $0.1 \mathrm{M} \mathrm{Na}_{2} \mathrm{HPO}_{4}-\mathrm{NaOH}$ buffer for $\mathrm{pH}$ $11-12$, and $0.1 \mathrm{M} \mathrm{KCl}-\mathrm{NaOH}$ buffer for $\mathrm{pH} 12-13$. One $\mathrm{mg}$ of casein was dissolved in $1.0 \mathrm{ml}$ of each buffer and incubated for $20 \mathrm{~h}$ at $16^{\circ} \mathrm{C}$. Then the solutions were neutralized and the degradation of casein in each buffer was measured by using the procedures of Robbins and Summaria (1976). The relative residual activity (\%) was assayed in comparison with the enzyme activity at $\mathrm{pH} 7.0$ as a control $(100 \%)$.

Effects of various inhibitors on the enzyme activity Each isoenzyme fraction $(1.0 \mathrm{mg} / \mathrm{ml})$ was dissolved in a $67 \mathrm{mM}$ phosphate buffer (pH 7.4) and preincubated for $10 \mathrm{~min}$ at $37^{\circ} \mathrm{C}$ in the presence of twelve inhibitors [phenylmethlysulfonyl fluoride (PMSF), pepstatin, aprotinin, trans-epoxysuccinyl-L-leucylamido-(4guanidino)-butane(E64), N-p-torsyl-L-lysine chloromrthyl ketone (TLCK), N-torsyl-L-phenylalanine chloromethyl ketone (TPCK), soybean trypsin inhibitor (SBTI), lima bean trypsin inhibitor (LBTI), leupeptin, chymostatin, elastinal, and EDTA (Sigma)]. Stock solutions of the inhibitors consisted of 0.01-1.0 mM in $\mathrm{H}_{2} \mathrm{O}$. After a 10-min treatment, the reactant solutions were dropped on the fibrin plate to detect changes in activity for $6 \mathrm{~h}$ at $37^{\circ} \mathrm{C}$. The relative residual activity (\%) was assayed in comparison with the lysis area $\left(\mathrm{mm}^{2}\right)$ by the enzyme with and without inhibitors as a control $(100 \%)$.

N-terminal sequence analysis The purified enzymes were used directly for an automated Edman degradation system, Milligen/ Biosearch M6000 protein sequencer. A search of the GenBank protein sequence data for a comparison of the sequence homology was done using the web site http://www.ncbi.nih.gov.

\section{Results and Discussion}

Purification of proteases with fibrinolytic activity from Earthworms One $\mathrm{kg}$ of the crude extract was obtained from the lysates of $10 \mathrm{~kg}$ of Lumbricus rubellus. It had 1.131 unit/mg specific activities on the casein substrate and contained $26.3 \%$ protein. The crude extracts were precipitated with 30-60\% ammonium sulfate, desalted, and freeze-dried.

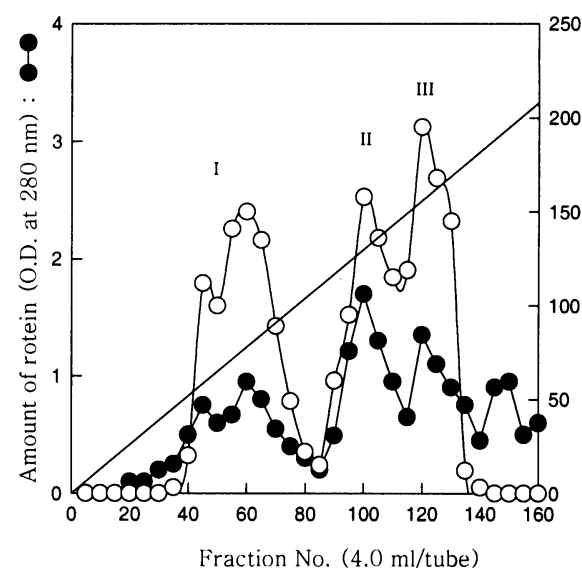

(A)

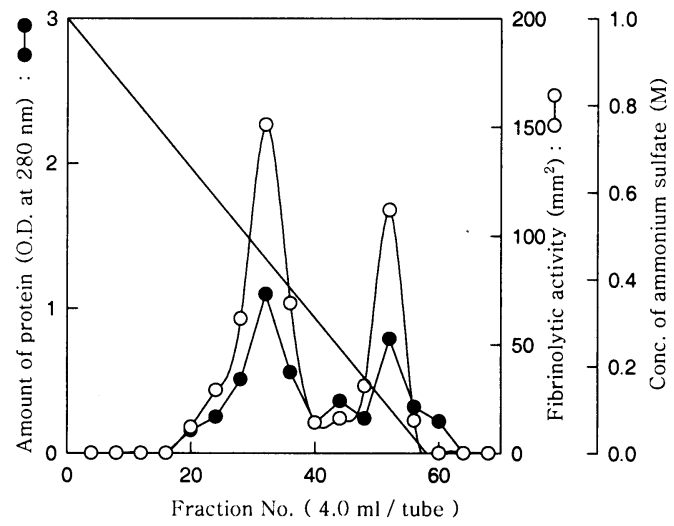

(B)

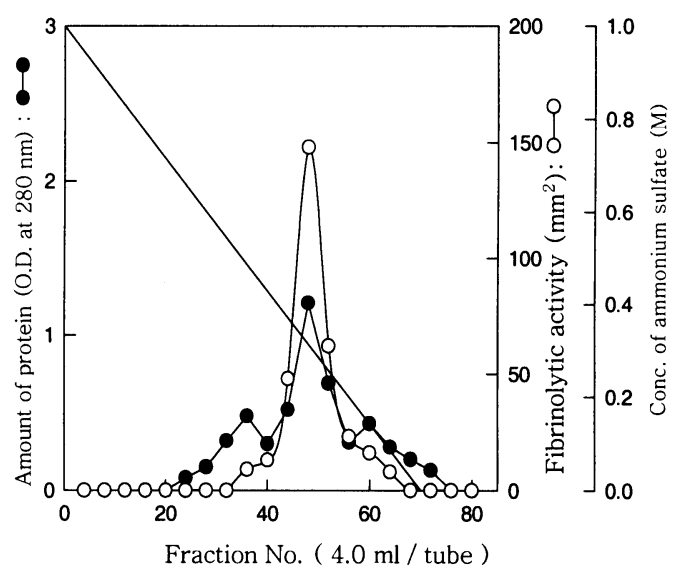

(C)

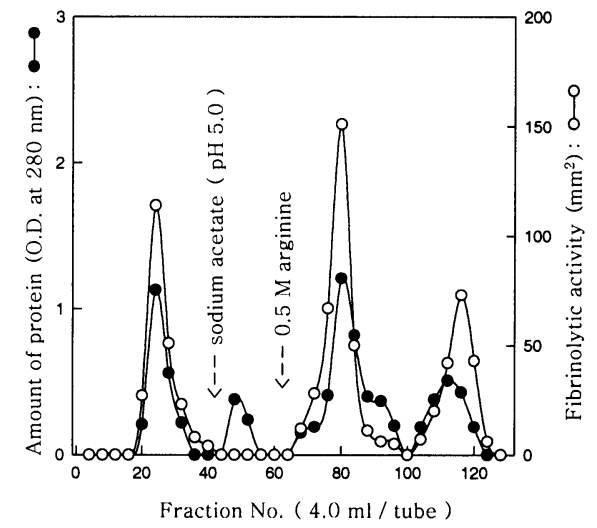

(D)

Fig. 1. Chromatography patterns of the purification procedure. (A) DEAE-chromatographic pattern. The bound proteins were eluted from 0 to $0.5 \mathrm{M} \mathrm{NaCl}$ solution. (B) Hydrophobic interaction chromatographic pattern of the DEAE-fraction I. (C) Hydrophobic interaction chromatographic pattern of the DEAE-fraction II. The bound proteins were eluted from 0-1.0 M ammonium sulfate solutions. (D) Affinity chromatographic pattern of the DEAE-fraction III. The bound proteins were eluted from 0 to $0.5 \mathrm{M}$ arginine solution. Details of the procedure are described in the Materials and Methods. Symbols: $(\boldsymbol{O})$ total proteins; $(\bigcirc)$ fibrinolytic activity $\left(\mathrm{mm}^{2}\right)$. 


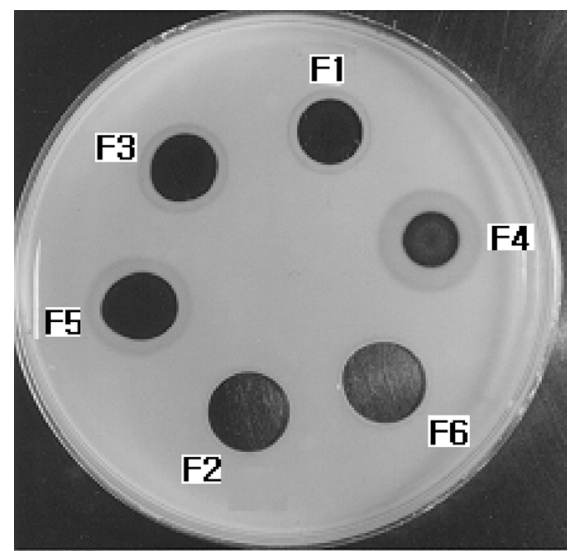

Fig. 2. Fibrinolytic activity of the LK fractions on fibrin plates. A 5\% fibrinogen solution was prepared using a fibrin plate buffer. Then, $10 \mathrm{ml}$ of the mixture was distributed into sterile petri-dishes, and $50 \mu \mathrm{l}$ of $20 \mathrm{NIH}$ units $/ \mathrm{ml}$ of the thrombin solution were slowly mixed in each dish and solidified for $1 \mathrm{~h}$ at room temperature. Next, $10 \mu \mathrm{l}$ of each LK fraction was dropped onto the fibrin plates and incubated for $15 \mathrm{~h}$ at $37^{\circ} \mathrm{C}$. After incubation, the mean diameters of the hydrolyzed clear zone were measured.

Finally, $44 \mathrm{~g}$ of the lumbrokinase (LK) ammonium sulfate powder was obtained. It had $17.3 \mathrm{unit} / \mathrm{mg}$ specific activities on the casein substrate and contained $94.7 \%$ protein. The crude LK enzymes were further purified using an ultrafilteration system and chromatographed (Fig. 1). The DEAE showed three enzyme peaks (I, II, III) having high fibrinolytic activity (Fig. 1A). The DEAE fraction I was divided into two fraction peaks (named F1 and F2) (Fig. 1B), whereas the DEAE fraction II was not subdivided and fractioned as only one peak (F3) (Fig. 1C) by hydrophobic interaction chromatography. The DEAE-fraction III was subdivided into three fraction peaks (named F4, F5, and F6) by the benzamidine sepharose 6B column (Fig. 1D). The F4 fraction, which was not attached on the column, was collected and the F5 and F6 fractions, which were attached on the column, were obtained by eluting with the arginine gradient. The six fractions showed fibrinolytic activities on the fibrin plates (Fig. 2). These results are similar to the results shown in the reports of Mihara et al. (1991) and Nakajima et al. (1993), wherein they found six fractions and proteolytic activities. The rank order of the fibrinolytic activity of the six fractions on the fibrin plates was $\mathrm{F} 6>\mathrm{F} 2>\mathrm{F} 5>\mathrm{F} 3>\mathrm{F} 1>\mathrm{F} 4$ (Fig. 2). The LK iso-enzymes were shown to be homogeneous on $12 \%$ SDS-PAGE (Fig. 3). The enzymes migrated as only one band on SDS-PAGE, under both reducing and non-reducing conditions (data not shown). These findings are also similar to results given by Nakajima et al. (1993). The molecular weights of the six fractions, F1 to F6, were 24.6, 26.8, 28.2, 25.4, 33.1, and 33.0 $\mathrm{kDa}$, respectively (Fig. 3, Table 1). The molecular weights, which were reported by Mihara et al. (1991), ranged from 23.5 to $34.2 \mathrm{kDa}$, which is similar to the data shown here.

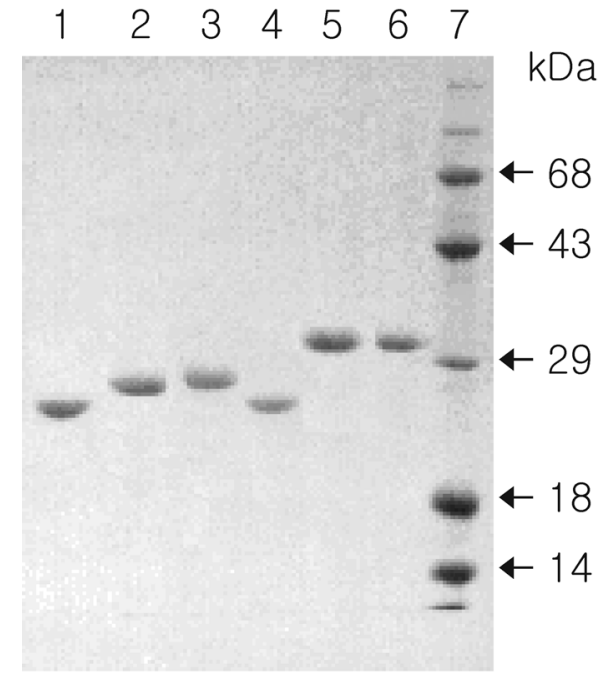

Fig. 3. SDS-polyacrylamide gel electrophoresis pattern of the LK fractions that were obtained from the $L$. rubellus lysates. Lanes 1, F1; 2, F2; 3, F3; 4, F4; 5, F5; 6, F6 fractions, and 7, molecular weight markers. The numbers on the right correspond to the positions of the molecular weight markers (bovine serum albumin $68 \mathrm{kDa}$, ovalbumin $43 \mathrm{kDa}$, carbonic anhydrase $29 \mathrm{kDa}$, $\beta$-lactogloblin $18 \mathrm{kDa}$, and lysozyme $14 \mathrm{kDa}$ ).

However, the molecular weights that were reported by Nakajima et al. (1993) were from 24 to $43 \mathrm{kDa}$, which differs from these findings. This means that, although the LK isoenzymes were showing similar fibrinolytic activity, their sources and molecular weights were different. Based on these results, each enzyme was considered to consist of a single polypeptide chain.

Characteristics of proteases with proteolytic and fibrinolytic activity The activity of casein degradation by the LK fractions is shown in Table 1. Proteolytic activity ranged from 11.3 to 167.5 units per $\mathrm{mg}$ with the rank order of the activity being $\mathrm{F} 2>\mathrm{F} 1>\mathrm{F} 5>\mathrm{F} 6>\mathrm{F} 3>\mathrm{F} 4$. F2 showed the highest degradation activity (167.5 units per $\mathrm{mg}$ ) on the casein substrate.

The fibrinolytic activities of the LK fractions on the fibrin plates were from 20.8 to 207.2 units per mg (Table 1). Their activity orders were $\mathrm{F} 6>\mathrm{F} 2>\mathrm{F} 5>\mathrm{F} 3>\mathrm{F} 1>\mathrm{F} 4$. The F6 fraction showed the highest hemolytic activity (207.2 units per $\mathrm{mg}$ ). Therefore, this F6 fraction iso-enzyme was used for cloning and sequencing. The iso-enzymes showed different activities according to the substrates.

The estimated activation $\left(\mathrm{mm}^{2}\right)$ of plasminogen to plasmin by the six iso-enzymes on the plasminogen-rich fibrin plate to the control plasminogen-free plate for $7 \mathrm{~h}$ at $37^{\circ} \mathrm{C}$ appeared to be $115 \mathrm{~mm}^{2}: 123 \mathrm{~mm}^{2}$ in the F1 enzyme (1.06 times), 286 : 302 (1.05 times) in F2, $167: 178$ (1.06 times) in F3, $87: 90$ (1.03 times) in F4, $224: 411$ (1.83 times) in F5, and $580: 961$ (1.65 times) in F6 (Fig. 4). The F5 and F6 iso-enzymes showed the highest activity when compared to the rich group 
Table 1. Molecular weights and proteolytic activities of the purified LK fractions

\begin{tabular}{cccccrr}
\hline \multirow{2}{*}{ Substrates } & \multicolumn{6}{c}{ MW and proteolytic activity (unit/mg) of the LK fractions } \\
\cline { 2 - 7 } & F1 & F2 & F3 & F4 & F5 & F6 \\
\hline kDa & 24.6 & 26.8 & 28.2 & 25.4 & 33.1 & 33.0 \\
Fibrin & 66.4 & 162.5 & 74.4 & 20.8 & 137.5 & 207.2 \\
Casein & 94.1 & 167.5 & 14.7 & 11.3 & 36.1 & 27.2 \\
\hline
\end{tabular}

MW: molecular weight
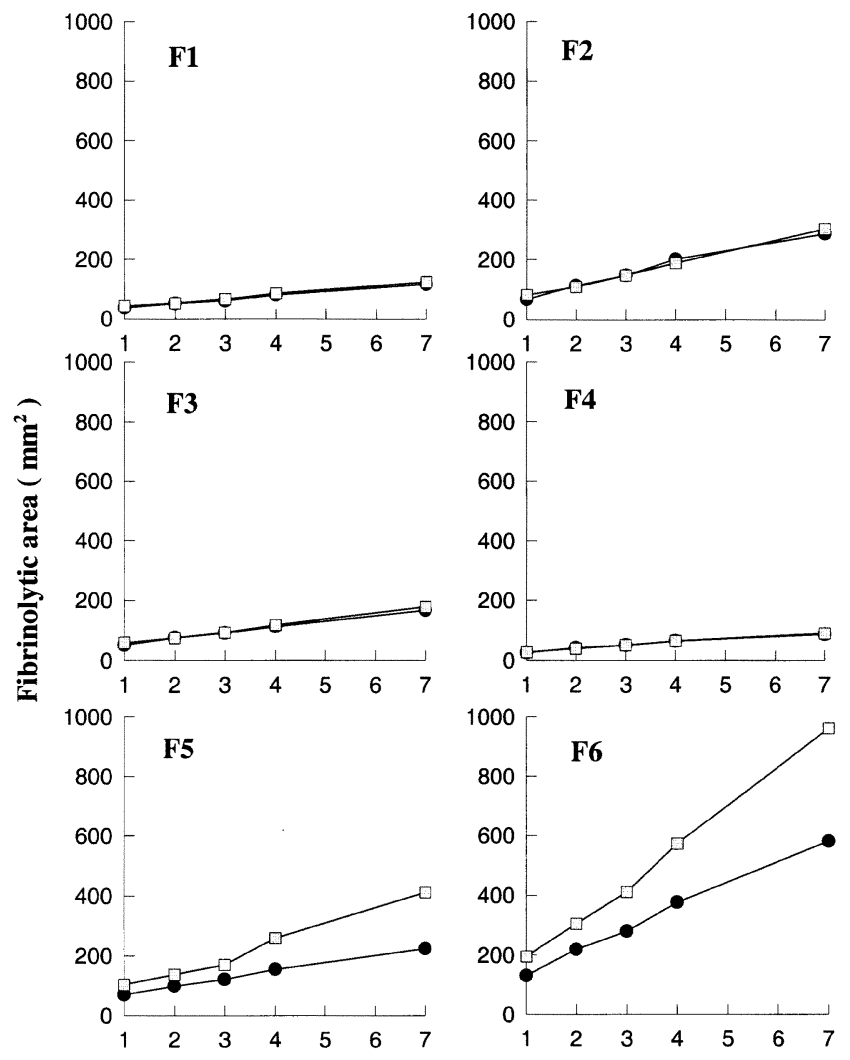

Time (h)

Fig. 4. Plasminogen activation by the six iso-enzyme fractions from $L$. rubellus. The fibrinolytic activity on the plasminogen was measured using a fibrin plate in the presence or absence of plasminogen. Symbols: $(\square)$, plasminogen-free plate and $(\boldsymbol{O})$, plasminogen rich plate.

with the free group. These results indicate that the F5 and F6 iso-enzymes highly activated plasminogen to plasmin on the fibrin plates.

The activity and stability of the six iso-enzymes from $L$. Rubellus were estimated by using the degradation of casein after treating the enzymes at various temperatures between $50-70^{\circ} \mathrm{C}$ for $3 \mathrm{~h}$ (Fig. 5). The six iso-enzymes showed $100 \%$ of their activities in $50^{\circ} \mathrm{C}$ for $3 \mathrm{~h}$, but their activities gradually decreased 80 to $91 \%$ in $55^{\circ} \mathrm{C}$. In $60^{\circ} \mathrm{C}$ and $65^{\circ} \mathrm{C}$, the enzyme activities deeply sloped down 25 to $2 \%$, and in $70^{\circ} \mathrm{C}$ their

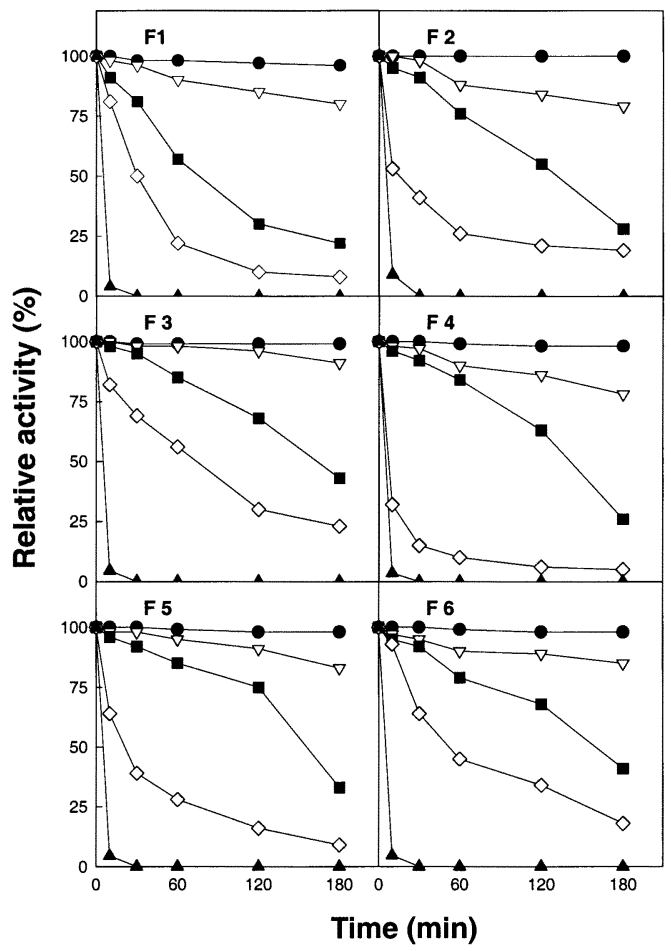

Fig. 5. Thermal stability of the six iso-enzymes from $L$. rubellus. Residual activities were expressed as the percentage of relative activity when compared with the untreated control. Symbols: $(\boldsymbol{\Delta})$, $70^{\circ} \mathrm{C} ;(\diamond), 65^{\circ} \mathrm{C} ;(\boldsymbol{\square}), 60^{\circ} \mathrm{C} ;(\nabla), 55^{\circ} \mathrm{C}$, and $(\bigcirc), 50^{\circ} \mathrm{C}$.

activities were completely lost. These results indicate that the optimal temperature for the six iso-enzymes appeared to be $50^{\circ} \mathrm{C}$.

The $\mathrm{pH}$ effects on the six iso-enzymes activity were examined in various buffers with a $\mathrm{pH}$ range from 2 to 13 by using the degradation of casein (Fig. 6). At pH 2, the activities of the six iso-enzymes were completely lost, and at $\mathrm{pH} 3$ their activities were about 70 to $80 \%$. In the range of $\mathrm{pH} 4-12$, the optimal activities and stabilities of the six iso-enzymes were maintained.

Protease inhibitor assay The six iso-enzymes from $L$. rubellus were applied to the twelve enzyme activity inhibitors to detect their inhibition patterns (Table 2). The four isoenzymes (F1, F2, F3, and F4) were completely inhibited by $1.0 \mathrm{mM}$ PMSF, and about $42 \%$ of the F5 iso-enzyme and $33 \%$ 


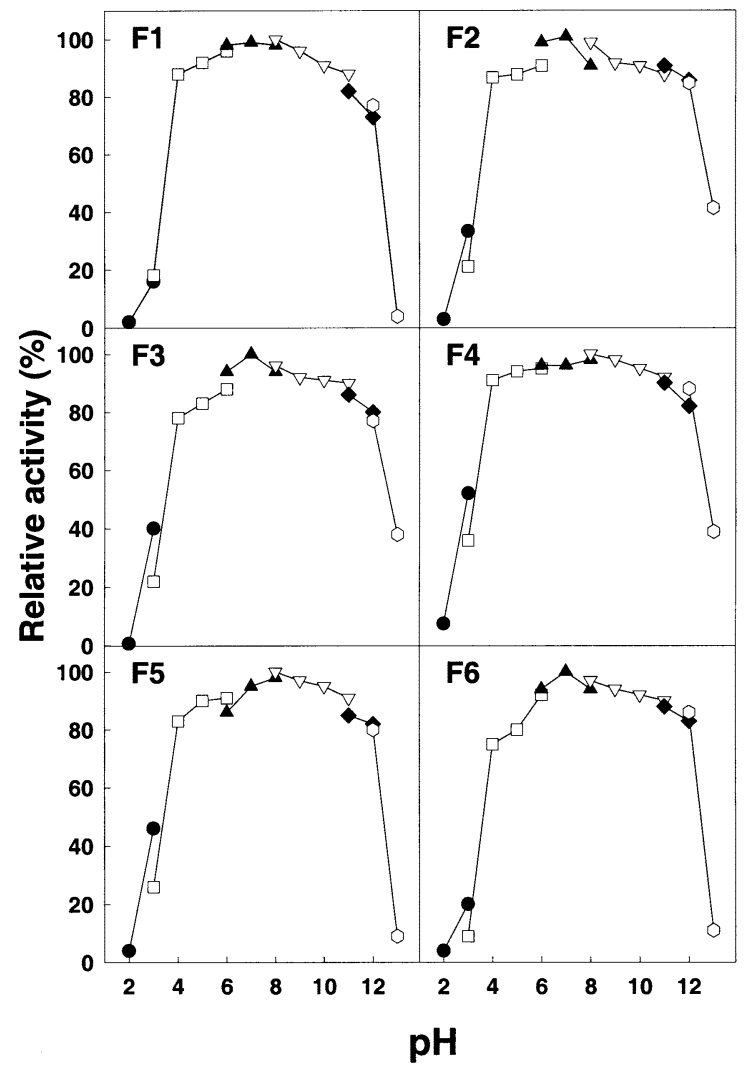

Fig. 6. The $\mathrm{pH}$ stability of six iso-enzymes from $L$. rubellus. The enzyme fractions were exposed to various buffer (described in Materials and Methods) for $20 \mathrm{~h}$ at $16^{\circ} \mathrm{C}$. Symbols: $(\mathbf{O}), \mathrm{pH} 2-$ 3; $(\square), \mathrm{pH} 3-6$; $(\boldsymbol{\Delta}), \mathrm{pH}$ 6-8; $(\nabla), \mathrm{pH}$ 8-11; $(\diamond), \mathrm{pH} 11-12$, and $(\diamond)$, pH 12-13.

of F6 were inhibited by PMSF. With these results, the isoenzymes could be classified as serine protease (Cho et al.,
1999; Choi et al., 2001). Aprotinin, TLCK, TPCK, SBTI, LBTI, and leupeptin completely inhibited the iso-F5 and F6 iso-enzyme. Therefore, these enzymes could be classified as trypsin-like serine protease (Choi et al., 2001). Chymostatin completely inhibited the activity of the F1 enzyme, but it did not inhibit the others. E64, pepstatin, EDTA, and elastinal did not inhibit any of the six iso-enzymes.

Analysis of the N-terminal amino acid sequences of the six iso-enzymes The $\mathrm{N}$-terminal amino acid sequences of the first 20 to 22 residues of each fraction were determined using the automated sequencer (Table 3 ). The iso-enzymes had high homology sequences and identical amino acid residues at the 3rd-4th and 13-15th regions. These results are consistent with the reports of Nakajima et al. (1993). The N-terminal 21-22 amino acid sequences of the F2, F3, and F4 enzymes were almost the same, whereas the N-terminal 22 amino acid sequences of F5 and F6 were identical. However, the molecular weights of the six iso-enzymes were different. These results suggest that these six iso-enzymes are not products of proteolytic cleavage during purification. These results also indicate that the enzymes were single polypeptide chains. Nakajima et al. (1993) reported that the 1 and 2 fractions were identical, as were the 4 and 5 fractions, whereas the other four fractions showed high homology. These reports show results that differ with our findings, although they show similar fibrinolytic activities. By comparing the amino acid sequences in the N-terminal regions of the F1 to F6 isoenzyme sequences with other sequences that are registered in the GenBank data (http//www.ncbi.nih.gov), they showed a $50 \%$ homology with trypsin-mRNA, trypsin-like enzyme mRNA, trypsinogen-mRNA, and trypsin activation peptide mRNA.

It could be concluded that the six lumbrokinase fractions

Table 2. Effect of inhibitors on fibrinolytic activity of lumbrokinase fractions from L. rubellus

\begin{tabular}{|c|c|c|c|c|c|c|c|}
\hline \multirow{2}{*}{ Inhibitors } & \multirow{2}{*}{$\begin{array}{l}\text { Conc } \\
(\mathrm{mM})\end{array}$} & \multicolumn{6}{|c|}{ Residual activity (\%) of lumbrokinase fractions } \\
\hline & & F1 & $\mathrm{F} 2$ & F3 & $\mathrm{F} 4$ & F5 & F6 \\
\hline NONE & & 100 & 100 & 100 & 100 & 100 & 100 \\
\hline PMSF & 1 & 0 & 0 & 0 & 0 & 58.3 & 67.3 \\
\hline E64 & 0.01 & 100 & 100 & 100 & 100 & 100 & 100 \\
\hline Pepstatin & 1 & 100 & 100 & 100 & 100 & 98.4 & 97.6 \\
\hline EDTA & 1 & 100 & 100 & 100 & 100 & 100 & 100 \\
\hline Aprotinin & 0.01 & 0 & 84.7 & 72.7 & 61.6 & 0 & 0 \\
\hline TLCK & 0.1 & 100 & 97.4 & 96.7 & 93.1 & 0 & 0 \\
\hline TPCK & 0.1 & 73.7 & 97.4 & 100 & 98.4 & 96.6 & 98.7 \\
\hline LBTI & 0.01 & 50.8 & 0 & 100 & 52.1 & 0 & 0 \\
\hline SBTI & 0.01 & 0 & 75 & 0 & 77.1 & 0 & 0 \\
\hline Leupeptin & 0.1 & 100 & 91.5 & 90.7 & 94.3 & 0 & 0 \\
\hline Chymostatin & 0.1 & 0 & 95.3 & 100 & 94.3 & 74.5 & 72.3 \\
\hline Elastatinal & 0.1 & 100 & 94.3 & 84 & 93.2 & 100 & 100 \\
\hline
\end{tabular}

PMSF, phenylmethylsulfonyl fluoride; E64, trans-Epoxysuccinyl-L-leucylamido-(4-guanidno)butane; TLCK, N-p-torsyl-L-lysine chlorom-ethyl ketone; TPCK, N-Torsyl-L-phenylalanine chloromethyl ketone; SBTI, soybean trypsin inhibitor; LBTI, lima bean trypsin inhibitor. 
Table 3. N-terminal amino acid sequences of the purified LK fractions

\begin{tabular}{|c|c|c|c|c|}
\hline \multicolumn{2}{|c|}{ Fractions } & \multicolumn{3}{|c|}{ N-terminal amino acid sequences } \\
\hline No. & 1 & 10 & 15 & 20 \\
\hline $\mathrm{F} 1$ & \multicolumn{4}{|c|}{ V-V-G-G-S-D-T-T-I-G-Q-Y-P-H-Q-L-S-L-R-V-T-G } \\
\hline $\mathrm{F} 2$ & \multicolumn{4}{|c|}{ I-I-G-G-S-N-A-S-P-G-E-F-P-W-Q-L-S-Q-T-R-G } \\
\hline F3 & \multicolumn{4}{|c|}{ V-I-G-G-T-N-A-S-P-G-E-F-P-W-Q-L-S-Q-Q-R-Q } \\
\hline $\mathrm{F} 4$ & \multicolumn{4}{|c|}{ V-I-G-G-T-D-A-A-P-G-E-F-P-W-Q-L-S-Q-T-R } \\
\hline F5 & \multicolumn{4}{|c|}{ I-V-G-G-I-E-A-R-P-Y-E-F-P-W-Q-V-S-V-R-R-K-S } \\
\hline F6 & \multicolumn{4}{|c|}{ I-V-G-G-I-E-A-R-P-Y-E-F-P-W-Q-V-S-V-R-R-K-S } \\
\hline
\end{tabular}

with fibrinolytic activity were purified from the earthworm $L$. rubellus lysates. The molecular weights of each iso-enzyme were from 24.6 to $33.0 \mathrm{kDa}$. The plasminogen was activated into plasmin by the enzymes. The optimal temperature of the six iso-enzymes was $50^{\circ} \mathrm{C}$. The optimal $\mathrm{pH}$ ranged from $\mathrm{pH} 4-$ 12. The four iso-enzymes were completely inhibited by PMSF. The two enzymes were completely inhibited by the six inhibitors. The N-terminal amino acid sequences of each fraction had high homology. The N-terminal of F5 and F6 were identical. Further studies are necessary for the elucidation of their medicinal applications and molecular biological characteristics.

Acknowledgments This work was supported by a Korea Research Foundation Grant (KRF-2000-015-DP0312).

\section{References}

Astrup, T. and Mullertz, S. (1952) The fibrin plate method for estimating fibrinolytic activity. Arch. Biochem. Biophy. 40, 346351.

Cho, S. Y., Hahn, B. S. and Kim, Y. S. (1999) Purification and characterization of a novel seine protease with fibrinolytic activity from Tenodera sinensis (Chinese mantis) egg cases. $J$. Biochem. Mol. Biol. 32, 579-584.

Choi, N. S., Kim, B. Y., Lee, J. Y., Yoon, K. S., Han, K. Y. and Kim, S. H. (2002) Relationship between acrylamide concentration and enzymatic activity in an improved single fibrin zymogram gel system. J. Biochem. Mol. Biol. 35, 236238.

Choi, N. S. and Kim, S. H. (2001) The effect of sodium chloride on the serine-type fibrinolytic enzymes and the thermostability of extracellular protease from Bacillus amyloliquefaciens DJ-4.
J. Biochem. Mol. Biol. 34, 134-138.

Jeon, O. H., Moon, W. J. and Kim, D. S. (1995) An anticoagulant/fibrinolytic protease from Lumbricus rubellus. $J$. Biochem. Mol. Biol. 28, 138-1452.

Laemmli, U. K. (1970) Cleavage of structural proteins during the assembly of the head of bacteriophage T4. Nature 227, 680685.

Lee, S. K., Bae, D. H., Kwon, T. J., Lee, S. B., Lee, H. H., Park, J. H., Heo, S. and Johnson, M. G. (2001) Purification and characterization of a fibrinolytic enzyme from Bacillus sp. KDO-13 isolated from soybean paste. J. Microbiol. Biotechnol. 11, 845-852.

Mihara, H., Sumi, H., Yoneta, T., Mizumoto, H., Ikeda, R., Seikl, M. and Maruyama, M. (1991) A novel fibrinolytic enzyme extracted from the earthworm, Lumbricus rubellus. Jpn. J. Physiol. 41, 461-472.

Mihara, H., Yineta, T., Sumi, H., Soeda, M. and Maruyama, M. (1989) A possibility of earthworm powder as therapeutic agent for thrombosis. Thromb. Haemosta. 62, 545-549.

Mihara, H., Nakajima, N. and Sumi, H. (1993) Characterization of protein fibrinolytic enzyme in earthworm, Lumbricus rubellus. Biosci. Biotech. Biochem. 57, 1726-1731.

Nakajima, N., Mihara, H. and Sumi, H. (1993) Characterization of potent fibrinolytic enzymes in earthworm, Lumbricus rubellus. Biosci. Biotech. Biochem. 57, 1726-1730.

Park, Y., Ryu, E., Kim, H., Jeong, J., Kim, J., Shim, J., Jeon, S., Jo, Y., Kim, W. and Min, B. (1999a) Characterization of antithrombotic activity of lumbrokinase-immobilized polyurethane valves in the total artificial heart. Artif. Organs. 23, 210-214.

Park, S. Y., Kye, K. C., Lee, M. H., Sumi, H. and Mihara, I. (1989) Fibrinolytic activity of the earthworm extract. Thromb. Haemosta. 62, 545-550.

Park, Y. S., Cha, M. H., Yong, W. M., Kim, H. J., Chung, I. Y. and Lee, Y. S. (1999b) The purification and characterization of Bacillus subtilis tripeptidase (pepT). J. Biochem. Mol. Biol. 32, 239-246.

Robbins, K. C. and Summaria, L. (1976) Plasminogen and plasmin. Methods Enzymol. 45, 257-273.

Ryu, G. H., Han, D. K., Park, S. Y., Kim, M., Kim, Y. H. and Min, B. G. (1995) Surface characteristics and properties of lumbrokinase-immobilized polyurethane. J. Biomed. Mater. Res. 29, 403-409.

Ryu, G. H., Park, S., Kim, M., Han, D. K., Kim, Y. H. and Min, B. G. (1994) Antithrombogenicity of lumbrokinase immobilized polyurethane. J. Biomed. Mater. Res. 28, 10691077.

Scopes, R. K. (1987) Protein purification. Springer-Verlag Inc., New York, USA. 